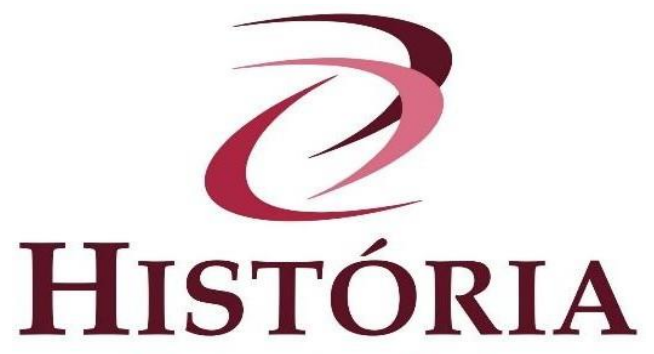

\title{
Na granicy Brazylijsko - Polskiej: współpraca naukowa w dziedzinie antropologii sądowej w służbie prawom czlowieka
}

\author{
At the Brazilian - Polish border: scientific cooperation in the field of forensic \\ anthropology in the service of Human Rights
}

\section{Na fronteira Brasil - Polônia: cooperação acadêmica em Antropologia Forense a serviço dos Direitos Humanos}

Streszczenie: Współpraca naukowa jest nieodłączną częścią współczesnych badań naukowych, niezależnie od dziedziny nauki. Niniejszy artykuł kontekstualizuje sytuację, która doprowadziła do spotkania polskich i brazylijskich naukowców, które zaowocowało bardzo efektywnym i owocnym partnerstwem naukowym. Współpraca początkowo przybrała formę post-doktoratu i rozwinęła się w skonsolidowaną grupę badawczą i międzynarodowy projekt badawczy. Wspólnym wątkiem wszystkich tych działań jest antropologia sądowa i jej rola w prawach człowieka.

Słowa kluczowe: antropologia sądowa, współpraca naukowa, Brazylia, Polska.

\begin{abstract}
Scientific partnership is an inherent part of contemporary academic research, independently on the field of science. The present article contextualizes the situation which led to the meeting of Polish and Brazilian researchers that would result in a very effective and fruitful academic partnership. The collaboration initially took form of a postdoctorate inquiry and developed into a consolidated research group and an international research project. A common thread of all these actions is forensic anthropology and its role in Human Rights.
\end{abstract}

Keywords: forensic anthropology, scientific collaboration, Brazil, Poland.

Resumo: A cooperação acadêmica é parte integrante da pesquisa acadêmica contemporânea, independentemente do campo da ciência. O presente artigo contextualiza a situação que levou ao encontro de uma pesquisadora polonesa com uma brasileira, o 
qual resultou em uma parceria acadêmica muito eficaz e proveitosa. A colaboração inicialmente tomou a forma de um pós-doutorado e desenvolveu-se em um grupo de pesquisa consolidado e em um projeto de pesquisa internacional. Uma linha comum a todas essas ações é a Antropologia Forense e seu papel nos Direitos Humanos.

Palavras-chave: antropologia forense, colaboração científica, Brasil, Polônia.

\section{Wprowadzenie}

W Brazylii przestępstwa naruszające prawo do życia (zabójstwa i wymuszone zaginięcia) osiągają bardzo wysoki poziom. Szacuje się, że w 2019 r. odnotowano ich około 100000 i podobną liczbę przewiduje się w $2020^{\mathrm{iii}} \mathrm{r}$. W przypadku osób zaginionych jest to około 80000 przypadków rocznie ${ }^{\text {iv }}$.

Nauki sądowe mają podstawowe znaczenie w procesie dochodzenia w sprawach kryminalnych. Z kolei antropologia sądowa, pośród różnych nauk zaangażowanych $\mathrm{w}$ ekspertyzę kryminalną, ma fundamentalne znaczenie w stawianiu czoła problemowi zmarłych i zaginionych, ponieważ wyznacza pole do praktyk, które dotyczą przede wszystkim identyfikacji człowieka, jak również jest podstawą do tworzenia nowej wiedzy w tym zakresie. Aby badania i ekspertyza antropologiczna miały wartość prawną, muszą być przeprowadzane rzetelnie, w oparciu o dane empiryczne i metody potwierdzone naukowo.

W praktyce, w Brazylii, analizy kryminalistyczne są wyłącznym atrybutem policji śledczej. Jednak właśnie ze względu na ich niezbędne podstawy naukowe, proces tworzenia wiedzy wspierającej późniejsze ekspertyzy rozpoczyna się w środowisku akademickim, poprzez szkolenie specjalistów, a także poprze badania naukowe, które generują i legitymizują nową wiedzę możliwą do wykorzystania w dochodzeniach. Mimo to, w Brazylii nie inwestuje się, w sposób skonsolidowany, w szkolenia akademickie - na poziomie odpowiednich stopni naukowych - dla policyjnych ekspertów śledczych, w dziedzinach takich jak na przykład archeologia czy antropologia sądowa, zawodach niezbędnych do rozwiązywania dochodzeń w przypadkach przestępstw przeciwko życiu. Pomimo iż eksperci zajmujący się w Brazylii antropologią sądową prywatnie inwestują we własne szkolenia i poszerzanie wiedzy, nie istnieje ujednolicone podstawowe wykształcenie, które uprawniałoby do rozpoczęcia pracy w tym zawodzie. Brak jest również wspólnych protokołów działania dla wszystkich stanów, które umożliwiałyby wymianę informacji $\mathrm{w}$ celu rozszerzenia analiz $\mathrm{z}$ zakresu archeologii $\mathrm{i}$ antropologii sądowej (GÓRKA; PLENS, 2020b). 
$\mathrm{Na}$ świecie, różni profesjonaliści praktykują antropologię sądową. Głównie są to antropolodzy $^{\mathrm{v}}$ (z wykształceniem w zakresie antropologii biologicznej/fizycznej), lekarze, archeolodzy i stomatolodzy. Aktualnie, zgodnie z wymogami American Board of Forensic Anthropology (ABFA) i Forensic Anthropology Society of Europe (FASE), dwóch wiodących stowarzyszeń zajmujących się postępem naukowym i certyfikacją antropologów sądowych, certyfikat antropologa sądowego jest przyznawany profesjonalistom w dziedzinie kryminalistyki z doktoratem z antropologii, ze szczególnym uwzględnieniem antropologii biologicznej/fizycznej. W przypadkach, gdy w niektórych kontekstach edukacyjnych nie jest oferowany doktorat $\mathrm{z}$ antropologii biologicznej lub sądowej, stowarzyszenia pozwalają na indywidualną ocenę każdego przypadku w celu certyfikacji (ABFA, 2020). Pomimo iż, w Brazylii kierunkiem akademickim, który obejmował kursy z zakresu antropologii biologicznej była przez długi czas archeologia, w praktyce, w ramach działania policji, wykształcenie archeologiczne nigdy nie zostało zaakceptowane do analizy i opracowania raportów antropologicznych.

W Brazylii, zgodnie z art. 159 Kodeksu postępowania karnego (BRASIL, 1941), ekspertami, którzy mogą wykonywać analizy z zakresu antropologii sądowej są profesjonaliści, którzy przystąpili do publicznego egzaminu. Tylko oficjalni eksperci (lekarz lub dentysta sądowy) mogą brać udział w analizach i przygotowywaniu oficjalnych raportów. Dodatkowo, wyłącznie lekarz sądowy ma prawo podpisywać raporty antropologiczne.

W społeczeństwie brazylijskim, te kwestie nigdy nie były w sposób szczególny poruszane czy kwestionowane. Dopiero, w momencie utworzenia Grupy Roboczej Perus (Grupo de Trabalho Perus - GTP), sytuacja ta zaczęła być problematyczna.

\section{Archeologia i antropologia sądowa}

W odróżnieniu od innych państw Ameryki Południowej, które również przeżyły terror dyktatury wojskowej w XX wieku, Brazylia, w niewielkim tylko stopniu odniosła się do kwestii osób zaginionych w wyniku tego przewrotu politycznego. Wśród państw, które podjęły się dochodzenia prawdy, w sposób szczególny wyróżnia się Argentyna i Argentyński Zespół Antropologii Sądowej (Equipe Argentina de Antropologia Forense EAAF).

Pomimo iż, EAAF nie był pierwszym zespołem na świecie, który przeprowadzał 
dochodzenia i analizy w sprawach przestępstw kryminalistycznych w sytuacjach konfliktowych (ROSENBLATT, 2015: 33), zespół ten wyróżniał się swoją wydajnością ze względu na argentyński kontekst historyczny. Doprowadził on do zaangażowania w cały proces członków rodzin osób zaginionych, którzy domagali się niezależnych od państwa śledztw, w celu rozwiązania przestępstw popełnianych przez samo państwo. Naciski ze strony argentyńskiego społeczeństwa spowodowały, że - na wniosek Krajowej Komisji ds. Zaginięcia Ludzi (Comissão Nacional de Desaparição das Pessoas CONADEP) i Babci z Plaza de Mayo (Abuelas de Plaza de Mayo), przy wsparciu i pomocy uznanych antropologów sądowych (Clyde Snow - USA) - został powołany multidyscyplinarny zespół - EAAF - składający się z archeologów, antropologów i lekarzy, których zadaniem była identyfikacja ciał i zwrócenie ich rodzinom, w ramach próby przeprowadzenia procesu zwanego sprawiedliwością okresu przejściowego (Transitional Justice). Jest to proces restrukturyzacji społeczeństwa obywatelskiego, które przeszło głęboki kryzys społeczny.

Od momentu powstania w 1984 do 2020, EAAF odnalazł i wydobył ponad 1400 ciał osób zaginionych w czasie dyktatury wojskowej w Argentynie i zidentyfikował ponad $800 \mathrm{z}$ nich (EAAF, 2020). Zespół brał również udział w śledztwach związanych ze zbrodniami przeciw ludzkości w ponad 30 krajach na całym świecie (min. Angoli, Bośni i Hercegowinie, Kosowie, Timorze Wschodnim, itp.).

To właśnie w kontekście argentyńskim, rola archeologów jako specjalistów z zakresu antropologii sądowej, stała się bardziej widoczna. Niemniej, w ostatnich dekadach, kształcenie zarówno w kierunku archeologii sądowej, jak i antropologii sądowej, zostało istotnie ustrukturyzowane w różnych rejonach świata, przede wszystkim w Stanach Zjednoczonych i Wielkiej Brytanii, tak by zapewnić każdemu z tych specjalistów odpowiednie wykształcenie do pracy w każdej z tych dziedzin. O ile zaangażowanie antropologów z gałęzi biologicznej/fizycznej w dziedzinie antropologii sądowej nie wymaga komentarza, możliwość takiego zaangażowania ze strony archeologów może, w pewnych kręgach, budzić wątpliwości. Niemniej jednak, zważywszy na fakt, że antropologia sądowa korzysta z metod pochodzących zarówno z dziedziny antropologii biologicznej/fizycznej, jak i archeologii (NAWROCKI, 2006), taka ewentualność jest jak najbardziej zasadna i stosowana w różnych kontekstach (np. EAAF czy EPAF).

Ogólnie rzecz ujmując, archeolodzy posiadają szerokie wykształcenie do pracy z różnymi kulturami materialnymi w celu interpretacji ludzkiego zachowania z przeszłości. 
Niektórzy z tych profesjonalistów specjalizują się w dziedzinie tzw. bioarcheologii, a tym samym są zaznajomieni z metodami antropologicznymi niezbędnymi do oceny płci, wieku, wysokości ciała czy pochodzenia, które wykorzystywane są w antropologii sądowej. Jednak, nie każdy archeolog specjalizuje się w bioarcheologii i będąc specjalistą w innej dziedzinie, takiej jak np. ceramika czy litologia, nie posiada niezbędnych kwalifikacji do analizy kości ludzkich. Jednak odpowiedni trening i specjalizacja mogą pomóc w późniejszej aktywności w kontekstach sądowych. Taka zmiana obszaru nie jest jednak automatyczna i wymaga odpowiednich szkoleń i doświadczenia w analizach sądowych (PLENS; SOUZA, 2019).

\section{Grupa Robocza Perus (Grupo de Trabalho Perus - GTP)}

Według Instytutu Vladimira Herzoga ${ }^{\mathrm{vi}}$, pod naciskiem członków rodzin osób zmarłych i zaginionych w trakcie trwania dyktatury wojskowej w Brazylii (1964 - 1985), wszystkie późniejsze demokratyczne rządy pracowały nad utworzeniem trzech komisji do prowadzenia dochodzeń $\mathrm{w}$ sprawach zbrodni popełnionych przez państwo brazylijskie w czasie reżimu wojskowego: Specjalnej Komisji ds. Zmarłych i Zaginionych Politycznie (Comissão Especial sobre Mortos e Desaparecidos Políticos), Komisji Amnestycznej (Comissão de Anistia) oraz Narodowej Komisji Prawdy (Comissão Nacional da Verdade).

Grupa Robocza Araguaia (Grupo de Trabalho Araguaia - GTA), została utworzona do analizy zbrodni popełnionych przez państwo brazylijskie na Partyzantce z Araguai w czasie dyktatury wojskowej, za które Brazylia została skazana przez Międzyamerykański Trybunał Praw Człowieka (Inter-American Court of Human Rights). GTA prowadziła śledztwo w celu zlokalizowania ciał zaginionych działaczy opozycji, jednak zanim udało się określić lokalizację ciała któregokolwiek z nich, prace grupy zostały wstrzymane z uwagi na możliwość ponownego skazania państwa brazylijskiego, tym razem za zbrodnie związane z masowym grobem w Perus (Vala de Perus). Dlatego też cała uwaga i środki zostały skierowane do Grupy Roboczej Perus (Grupo de Trabalho Perus - GTP).

Z obawy przed kolejnym skazującym wyrokiem, dopiero rząd Dilmy Roussef zdecydował się na utworzenie GTP w celu identyfikacji zaginionych działaczy opozycji, których ciała zostały najprawdopodobniej odnalezione w niezidentyfikowanym grobie masowym na cmentarzu Dom Bosco w Perus, w São Paulo. Niemniej, prace tego zespołu 
skupiać się miały jedynie na działaczach opozycji znajdujących się w grobie. Pozostałe zaginione osoby, których ciała również znaleziono w tym samym miejscu, nie zostały ujęte w projekcie (pomimo takiej sugestii ze strony prof. Plens, i późniejszej podobnej propozycji prof. John'a Albanese z Uniwersytetu w Windsor, Kanada). GTP, w początkowej fazie, miał wsparcie EAAF i Peruwiańskiego Zespołu Antropologii Sądowej (EPAF).

W celu implementacji projektu, przez wiele miesięcy prowadzona była dyskusja na temat tego jacy specjaliści powinni tworzyć ten zespół. Nie było możliwości, żeby oficjalni eksperci kryminalni z każdego stanu przenieśli się na pełny etat do miejsca gdzie odbywały by się analizy (Centrum Antropologii i Archeologii Sądowej przy Federalnym Uniwersytecie w São Paulo - CAAF/UNIFESP). Takie rozwiązanie wymagałoby porzucenia przez nich codziennych obowiązków w Instytutach Ekspertyz Sądowych (Instituto Medico-Legal - IML), gdzie są zatrudnieni, i zaangażowania się w długoterminowy projekt (badania rozpoczęły się w 2014 i do dnia dzisiejszego są kontynuowane), głównie w celu przygotowania odpowiednich protokołów działania do analizy 1049 kartonów z materiałem kostnym (całkowita liczba osobników do tej pory nie została jeszcze udostępniona opinii publicznej). W takiej sytuacji, zaczęto rozważać ewentualność zatrudnienia archeologów do pracy w GTP. Z jednej strony, oficjalni eksperci kryminalni, głównie lekarze sądowi, zdecydowanie zakwestionowali taką możliwość, głównie ze względu na fakt, iż zgodnie z prawem brazylijskim, jedynie oficjalni eksperci, wyłonieni w drodze konkursów publicznych mogą brać udział w śledztwach kryminalnych. Dodatkowym argumentem lekarzy był fakt, że tylko oni są uprawnieni do podpisywania oficjalnych raportów końcowych analizy ciała/szkieletu. Takie rozwiązanie oznaczałoby, że w przypadku innych specjalistów przeprowadzających analizę, aby sprawozdania miały jakąkolwiek ważność sądową, lekarz sądowy, który nie przeprowadzałby analiz, musiałby podpisać raporty i wziąć odpowiedzialność za wyniki. Jednak, pomimo takiego impasu, i z powodu braku specjalistów z zakresu antropologii biologicznej, najlepszym rozwiązaniem gwarantującym utworzenie GTP było stworzenie interdyscyplinarnego zespołu, który skupiałby się na zadaniach z antropologii sadowej, i który składał by się $\mathrm{z}$ oficjalnych ekspertów kryminalnych oraz wykładowców akademickich $\mathrm{w}$ grupie rotacyjnej, ale przede wszystkim - w oparciu o argentyńskie doświadczenia $-\mathrm{z}$ profesjonalistów $\mathrm{z}$ dziedziny archeologii $\mathrm{w}$ rdzeniu projektu, który pracowałby na pełny etat. Niestety, jak się później okazało, nie wszyscy zatrudnieni posiadali, w tamtym czasie, odpowiednie wykształcenie $\mathrm{z}$ zakresu archeologii. 
Dodatkowo, po opuszczeniu projektu przez EAAF, a później przez EPAF (Peruwiański Zespół Antropologii Sądowej - Equipe Peruano de Antropologia Forense), oraz pomimo iż projekt był utworzony we współpracy ze środowiskiem akademickim, dyrekcja i komitet naukowy nie wzięli odpowiedzialności za zatrudnianie naukowców i specjalistów, a skupili się na przedstawicielach policji cywilnej i federalnej. Tym samym, niezależność polityczna od struktur państwowych, niezbędna w tego typu śledztwach i tak podkreślana przez EAAF, nie została utrzymana w Brazylii.

Protokół postępowania dla GTP, stworzony w pierwszej fazie projektu przez EAAF i EPAF, bez udziału brazylijskich naukowców lub ekspertów kryminalnych tworzących zespół, na bazie różnorodnych metod stosowanych na całym świecie, okazał się być stosunkowo skomplikowany w obliczu tak zróżnicowanego wykształcenia i doświadczenia profesjonalistów, którzy mieli go stosować. Tym samym, niezbędne okazały się kursy dokształcające z zakresu stosowania poszczególnych metod.

Po pierwszych miesiącach aktywności w GTP, prof. Claudia Plens, rozmawiając z niektórymi ekspertami kryminalnymi, zauważyła, że istnieje pewnego rodzaju niepewność, w stosunku do metod zaproponowanych w protokole, odnośnie analizy osobników z populacji brazylijskiej. Równolegle, członkowie CAAF, zwłaszcza profesorowie i wykładowcy akademiccy, zauważyli konieczność stworzenia kursu z zakresu Antropologii Sądowej, w celu wzmocnienia tej dziedziny w Brazylii. W ten sposób na UNIFESP utworzony został kurs: Antropologia Sądowa i Prawa Człowieka, koordynowany przez prof. Plens. Kurs prowadzony jest przez międzynarodowych, uznanych antropologów sądowych oraz przez różnych brazylijskich specjalistów z zakresu nauk sądowych. Choć nie jest to jeszcze kurs pozwalający na nadanie stopnia naukowego, wielu profesjonalistom $\mathrm{z}$ całego terytorium Brazylii, pozwala na poznanie metod $\mathrm{i}$ protokołów stosowanych na świecie oraz przemyślenie ich własnych badań i sposobu działania w perspektywie światowej.

To właśnie w takim kontekście, dr Katarzyna Górka, magister i doktor w dziedzinie antropologii biologicznej, ze szczególnym zainteresowaniem naukowym skierowanym na antropologię sądową, spotkała się dr Claudią Plens, magistrem i doktorem archeologii, by wspólnie, w ramach rozwoju antropologii sądowej, skupić się na analizie tej dyscypliny w Brazylii. Biorąc pod uwagę fakt, iż nie do końca znane jest kim są osoby, które w Instytutach Ekspertyz Sądowych zajmują się dziedziną antropologii sądowej, dr Górka zaproponowała projekt post-doc, pod kierownictwem dr Plens, w ramach Programu Studiów Podyplomowych z Historii UNIFESP (Programa de Pós- 
Graduação em História), na który otrzymała grant ze środków Krajowej Rady ds. Rozwoju Naukowego i Technologicznego (CNPq) przy Ministerstwie Nauki, Technologii, Innowacji i Komunikacji (Pós-doutorado Júnior - PDJ).

\section{„W poszukiwaniu tożsamości - antropologia sądowa w Brazylii” - projekt post-doc dr Katarzyny Górki.}

Budowanie wysokiej jakości dyscypliny naukowej i zawodowej, która gwarantowałaby stosunkowo jednorodne wykształcenie profesjonalistów, regulację działalności zawodowej i standaryzację najbardziej niezawodnych procedur, co pozwoliłoby stawić czoła codziennym wyzwaniom oraz umożliwiłoby jak najlepszy rozwój tej dziedziny, wymaga wcześniejszego poznania sytuacji, koncepcji oraz profilu danej dyscypliny w konkretnym kontekście (CUNHA; CATTANEO, 2006). W tym celu został stworzony projekt post-doc, w ramach którego zaproponowano ocenę sytuacji antropologii sądowej w Brazylii, stosunkowo nowej dyscypliny, która nie została jeszcze skonsolidowana $\mathrm{w}$ tym kraju, a równocześnie jest niezwykle istotna w kontekście kryminalistycznym, ze względu na jej prawne zastosowania. Jakość projektu i konieczność tego typu badań została potwierdzona przez Krajową Radę ds. Rozwoju Naukowego i Technologicznego (CNPq), która przyznała dr Górce stypendium Pósdoutorado Junior (PDJ) na realizację jej badań.

Brak jest praktycznie jakichkolwiek danych na temat obszaru antropologii sądowej w Brazylii. Guimarães et al. (2015) wskazują, że aby zrozumieć rozwój tej dziedziny w tym kraju, konieczna jest kontekstualizacja jego historii. Sytuacja polityczna, szczególnie w okresie dyktatury wojskowej (1964-1985), ale także pewne decyzje legislacyjne ją poprzedzające, pokrywają się z fazą konsolidacji antropologii sądowej na całym świecie i stanowią czynniki, które w znacznym stopniu utrudniały rozwój tej dziedziny w Brazylii (GUIMARÃES et al., 2015). Dla rządów reżimu wojskowego bardzo wygodny był brak możliwość identyfikacji osób zaginionych w wyniku represji politycznych (GUIMARÃES, 2003; FRANCISCO et al., 2011). Biorąc pod uwagę kluczową rolę antropologii sądowej w identyfikacji szczątków ludzkich, wspomniany kontekst polityczny stanowi jeden z czynników wyjaśniających ogromne ograniczenia pod względem budżetu, warunków pracy, braku technologii i wyposażenia, a także znikome badania naukowe oraz brak nauczania nauk sądowych ogólnie, a w szczególności 
antropologii sądowej.

Dlatego też, propozycja dr Górki została przemyślana jako wielowymiarowe badanie ze szczególną uwagą zwróconą $\mathrm{w}$ stronę naukowego i zawodowego aspektu antropologii sądowej w Brazylii. Pierwsza cześć projektu została przeprowadzona w oparciu o analizę produkcji naukowej związanej z tą dyscypliną. Druga część obejmowała badania terenowe w głównych Instytutach Ekspertyz Sądowych (IML) w kraju. Projekt pozwolił na identyfikację najważniejszych centrów naukowych w zakresie tej dyscypliny, oceniono istnienie ośrodków dydaktycznych w tym obszarze oraz profil specjalistów. Wyniki umożliwiły także identyfikację i ocenę standaryzacji metod antropologii sądowej stosowanych w IML. Badanie pozwoliło na uzyskanie bezprecedensowego zestawu danych dotyczących antropologii sądowej w kontekście brazylijskim, co umożliwiło stworzenie szerokiego i głębokiego przeglądu tej dziedziny, a tym samym może przyczynić się do rozwoju i konsolidacji antropologii sądowej w Brazylii.

Projekt został ukończony w tym roku (2020), a jego dotychczasowym wymiernym wynikiem są dwie publikacje naukowe (GÓRKA; PLENS, 2020a, b) oraz wystąpienie kongresowe.

\section{Aspekt naukowy antropologii sądowej w Brazylii}

Dane statystyczne - wskaźniki bibliometryczne - uzyskane w wyniku analizy publikacji naukowych pozwalają na ocenę skali, rozmiaru i tendencji w produkcji wiedzy w określonej dziedzinie nauki (TARAZONA et al. 2017). Biorąc pod uwagę, że produktywność, rozwój i aktualny stan dyscypliny naukowej można ocenić poprzez kwantyfikację jej produkcji naukowej, pierwsza cześć projektu - The academic scenario of Forensic Anthropology in Brazil - dogłębnie analizuje działania, postępy i kierunki związane $\mathrm{z}$ badaniami $\mathrm{w}$ dziedzinie antropologii sądowej w Brazylii. Równocześnie, badanie miało na celu zrozumienie trudności i wyzwań oraz refleksję nad przyszłym rozwojem tego obszaru, z naukowego punktu widzenia, dlatego proponuje pewne środki i zalecenia, zarówno dla naukowców, jak i agencji rządowych, które mogą ułatwić i promować postęp oraz rozwój tej dziedziny w Brazylii.

W odniesieniu do danych uzyskanych podczas pierwszej części badań, zaobserwowaliśmy znaczny wzrost liczby publikacji naukowych w ciągu ostatnich 10 lat, co odpowiada niedawnemu (ponownemu) otwarciu się na tę dyscyplinę w Brazylii. 
Produkcja naukowa jest niemniej cały czas stosunkowo niska, jednak z tendencją do szybkiego wzrostu. Biorąc pod uwagę brak szkoleń i kierunków akademickich w zakresie antropologii biologicznej oraz fakt, że to przede wszystkim głownie dentyści wykonują czynności antropologów sądowych w IML, nie dziwi, że większość badań w tym zakresie jest przeprowadzana na wydziałach stomatologii i koncentruje się bardziej na stomatologii sądowej niż na antropologii sądowej. Najaktywniejszym ośrodkiem naukowym, zarówno z zakresie antropologii jak i stomatologii sądowej jest Uniwersytet w São Paulo (USP). Niemniej, same Instytuty Ekspertyz Sądowych, również okazały się ważnymi ośrodkami produkcji naukowej.

Współpraca naukowa, zwłaszcza międzynarodowa, jest wartością dodaną publikacji naukowej i często skutkuje dłuższym i częstszym cytowaniem pracy (LEE; BOZEMAN, 2005; SONNEWALD, 2007). W tym kontekście, produkcja wiedzy z zakresu antropologii i stomatologii sądowej w Brazylii pozostawia wiele do życzenia. Tylko nieco ponad połowa wszystkich przeanalizowanych artykułów została przygotowana we współpracy pomiędzy, co najmniej, dwiema różnymi instytucjami. W ostatnim dziesięcioleciu znacznie wzrosła liczba współautorów krajowych, ale internacjonalizacja badań cały czas jest stosunkowo niska. Dlatego, w celu zwiększenia znaczenia i jakości wiedzy wytwarzanej w Brazylii w dziedzinie antropologii sądowej oraz zwiększenia możliwości jej finansowania, brazylijscy naukowcy powinni w większym stopniu rozważyć możliwości współpracy, zwłaszcza międzynarodowej.

Powyższe badanie zostało przedstawione na III Krajowym Kongresie Antropologii Sądowej (2018) zorganizowanym przez Brazylijskie Stowarzyszenie Antropologii Sądowej (ABRAF), gdzie zostało nagrodzone jako najlepsza praca w kategorii podyplomowej.

\section{Sytuacja antropologii sądowej w Brazylii z punktu widzenia profesjonalistów}

Druga część projektu - In search of identity - the field of forensic anthropology in Brazil. Profession and practice - zawiera przegląd sytuacji zawodowej w dziedzinie antropologii sądowej w Brazylii, a tym samym wspiera rozwój tej dyscypliny i przyczynia się do poznania jej statusu w kontekście światowym. Szczegółowa analiza i interpretacja wyników sugeruje, że dziedzina antropologii sądowej, pomimo zaangażowania i poświęcenia jej specjalistów, nie może być jeszcze uważana za dobrze ustrukturyzowaną i 
rozwiniętą dyscyplinę $\mathrm{w}$ całym kraju. Istnieją istotne rozbieżności pod względem infrastruktury i zasobów kadrowych między brazylijskimi stanami, jak również $\mathrm{w}$ ogólnym postrzeganiu antropologii sądowej przez specjalistów. Różnice w infrastrukturze oraz kadrach można próbować wyjaśnić poprzez organizację administracyjną państwa i związanym z nią faktem, że Instytuty Ekspertyz Sądowych podlegają administracji stanowej, co automatycznie przekłada się na zróżnicowanie polityki oraz dystrybucji środków przeznaczonych na min. antropologię sądową, pomiędzy różnymi stanami. Taka organizacja państwa daje poszczególnym stanom autonomię w decydowaniu o różnych aspektach polityki wewnętrznej, ale równocześnie utrudnia budowanie i rozwój jednorodnych, ogólnopaństwowych strategii w obszarach o szczególnym znaczeniu publicznym, takich jak antropologia sądowa. Było to wyraźnie widoczne $\mathrm{w}$ trakcie naszych wizyt, gdzie zamożniejsze stany charakteryzowały się stosunkowo dostatecznie dofinansowaną infrastrukturą IML i posiadały przynajmniej dwóch przeszkolonych profesjonalistów, podczas gdy w innych brakowało najbardziej podstawowego sprzętu niezbędnego do odpowiedniego i skutecznego świadczenia usług, a zasoby ludzkie były bardzo ograniczone. Różnice te prowadzą do sytuacji, w której ludzie z tego samego kraju nie mogą oczekiwać takiej samej jakości usług od tych samych organów publicznych w różnych stanach. Sytuacja taka jest bardzo niekorzystna dla społeczeństwa, a w przypadku antropologii sądowej można ją uznać za naruszenie podstawowych praw człowieka (BARAYBAR i BLACKWELL, 2014). Dlatego też, istnieje pilna potrzeba stworzenia i opracowania ogólnopaństwowych strategii i polityki, które mogą poprawić i ujednolicić jakość usług antropologii sądowej w całym kraju.

Druga kwestia, związana z postrzeganiem antropologii sądowej w Brazylii, ma głębokie i dalekosiężne implikacje. Jak skomentowali niektórzy z naszych rozmówców, ze względu na kontekst historyczny, niektóre instytucje w Brazylii zdecydowanie odrzucają antropologię biologiczną / fizyczną, która w pewnych kręgach, w dalszym ciągu postrzegana jest jako nauka będąca pretekstem rasizmu. To przekłada się na praktycznie całkowity brak ofert edukacyjnych z tej dziedziny na jakimkolwiek poziomie nauczania ${ }^{\text {vii }}$ (GASPAR NETO, 2017), które mogłyby służyć jako podstawa do późniejszej specjalizacji w antropologii sądowej. Taka sytuacja ma dwie istotne konsekwencje. Z jednej strony poważnie ograniczony jest dostęp do wysokiej jakości podstawowego wykształcenia dla przyszłych antropologów sądowych - opinia ta jest szeroko podzielana przez ankietowanych specjalistów. Z drugiej strony, brak kursów z zakresu antropologii biologicznej / fizycznej w programie akademickim, a także brak uwzględnienia tej 
dyscypliny przez wielu naukowców i specjalistów, delegitymizuje i podważa możliwe korzyści z jej zastosowania w przypadkach kryminalistycznych. Na taką sytuację również często wskazywali nasi rozmówcy. Brak zaufania do metod bioantropologicznych stosowanych w kontekście kryminalistycznych, w wielu przypadkach uniemożliwia lub przynajmniej utrudnia pozytywne rozstrzygnięcie sprawy.

Badania dr Górki nakreśliły bardzo jasny obraz rzeczywistości antropologii sądowej w Brazylii. Brak akademickich i specjalistycznych opcji szkoleniowych, brak materiałów porównawczych, niewystarczające inwestycje, brak odpowiedniej infrastruktury / wyposażenia oraz znaczne przeciążenie pracą zbyt małej liczby specjalistów stanowią największe wyzwania dla tej dyscypliny w Brazylii. Ponadto, ograniczona współpraca pomiędzy różnymi sekcjami tego samego IML oraz niewystarczająca komunikacja pomiędzy Instytutami z różnych stanów, a także ogólny brak zaufania co do przydatności analiz antropologicznych w przypadkach kryminalistycznych - szczególnie u osób decyzyjnych w strukturach IML - utrudniają rozwój tej dyscypliny. Dodatkowo, istnieją również istotne strukturalne i biurokratyczne trudności w prowadzeniu badań naukowych wewnątrz IML. Istnieje jednak duże otwarcie na współpracę naukową, mnóstwo materiału i pilna potrzeba takich inicjatyw.

Pomimo wszystkich wyżej wymienionych trudności i ograniczeń, należy podkreślić duży profesjonalizm i poświęcenie większości specjalistów, którzy pełnią funkcje antropologów sądowych w różnych Instytutach Ekspertyz Sądowych w całym kraju. Pracownicy tego sektora wkładają duży wysiłek w poprawę, rozwój oraz zwiększenie widoczności i zainteresowania tą dyscypliną. Pomimo trudnych okoliczności, braku odpowiedniego wykształcenia i ustrukturyzowanych opcji szkoleniowych, na przekór ograniczeniom infrastrukturalnym spowodowanym niewystarczającym wsparciem finansowym ze strony państwa, ich poczucie obowiązku, motywacja i ciekawość przeważają. Brak możliwości zdobycia niezbędnych podstaw naukowych nie obniża jakości świadczonych przez nich usług - wręcz przeciwnie. Jak zauważyła Cunha (2019), wielu specjalistów (choć niestety nie większość) ściśle monitoruje światowy rozwój tej dyscypliny i aktywnie uczestniczy w kongresach, warsztatach i szkoleniach. Ich poświęcenie i osobiste zaangażowanie, niezależnie od trudnych warunków i niedofinansowania obszaru, były wyraźnie widoczne podczas osobistych wizyt i wywiadów, a jakość świadczonych przez nich usług powinna zostać doceniona.

Projekt post-doc przeprowadzony przez dr Górkę wykazał istotne ograniczenia strukturalne, polityczne i akademickie, które wpływają na dziedzinę antropologii sądowej 
w Brazylii. Jednak poświęcenie i etyczne nastawienie profesjonalistów wskazują na potencjał ludzki jako główną siłę tej dyscypliny, która wspiera i umożliwia badania, zapewniając wysokiej jakości usługi w kontekście pozbawionym odpowiedniej infrastruktury i szkoleń na różnych poziomach.

Oprócz samych badań, w okresie post-doc na UNIFESP, dr Górka intensywnie działała również na rzecz promocji zarówno antropologii sądowej, jak i antropologii biologicznej w brazylijskim środowisku akademickim. Przeprowadziła kurs: „Zastosowanie antropologii biologicznej w służbie prawom człowieka” dla studentów historii w Escola de Letras, Filosofia e Ciências Humanas, UNIFESP. Została zaproszona na konferencję na temat swoich badań dla grupy badawczej w dziedzinie antropologii sądowej (LANFOR) na Federalnym Uniwersytecie Santa Catarina. Wygłosiła wykład na temat trudnego tematu rasy / pochodzenia w antropologii: „Kwestia rasy w antropologii” dla studentów stosunków międzynarodowych w Centro de Ciências Humanas da Universidade Federal de Roraima oraz została zaproszona do przeprowadzenia kursu: „Wprowadzenie do antropologii biologicznej i zasad identyfikacji człowieka” podczas 13. Tygodnia Nauki i Technologii na Universidade Estadual de Roraima. Dzięki tym doświadczeniom zauważyła bardzo duże zainteresowanie zarówno studentów, jak i pracowników naukowych antropologią biologiczną i jej zastosowaniami kryminalistycznymi. Pozostawia to nadzieję na przyszły rozwój tych obszarów, o ile społeczeństwo w wystarczającym stopniu będzie się tego domagać.

\section{Laboratorium Badań Archeologicznych}

Równolegle do badań dr Górki, wewnątrz Laboratorium Badań Archeologicznych (Laboratório de Estudos Arqueológicos - LEA), prof. Cláudia Plens stworzyła akademicką przestrzeń naukową w dziedzinie antropologii i archeologii sądowej oraz praw człowieka. Tworzą ją dwie grupy badawcze finansowane przez CNPq: Centrum Nauki i Badań w Archeologii i Antropologii Sądowej (Núcleo de Ensino e Pesquisa em Arqueologia e Antropologia Forense - NEPAAF) oraz Terytoria i Prawa Człowieka (Territórios e Direitos Humanos).

Począwszy od projektu walidacji metod antropologii sądowej: „Budowanie praw człowieka poprzez kwalifikacje zawodowe i badania $\mathrm{w}$ antropologii sądowej $\mathrm{w}$

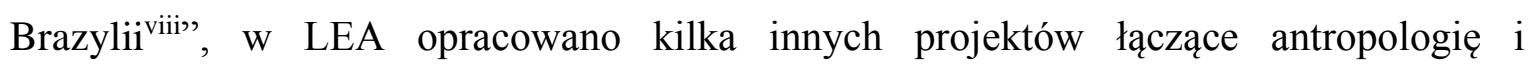


archeologię sądową, prawa człowieka i problematykę rdzennych społeczności Brazylii. Aktualnie, na bazie konceptu opracowywanego od dawna przez prof. Plens oraz w wyniku współpracy różnych specjalistów i LEA, stworzony został międzynarodowy zespół pod kierownictwem prof. Plens i przy współpracy prof. Ivan'a Rocsandik'a z University of Winnipeg, Kanada oraz dr Katarzyny Górki z Polskiej Akademii Nauk, którego celem jest realizacja projektu łączącego badania z dziedziny antropologii językowej i kulturowej, archeologii klasycznej oraz archeologii i antropologii sądowej oraz praw człowieka. Projekt, który jest w początkowej fazie, otrzymał finansowanie $\mathrm{z}$ prestiżowej Transatlantyckiej Platformy Innowacji Społecznych (Trans-Atlantic Platform for Social Innovation), a także wsparcie z Centrum Zasobów Humanitarnych i Praw Człowieka (Humanitarian and Human Rights Resource Center - HHRRC) Amerykańskiej Akademii Nauk Sądowych (American Academy of Forensic Sciences - AAFS) oraz National Institute of Justice (US) za pośrednictwem programu centrum doskonałości kryminalistycznej (Forensic Technology Center of Excellence Program, RTI International) na rozwój części badawczej zespołu brazylijskiego.

Ten wielodyscyplinarny projekt ma na celu wykorzystanie wiedzy z dziedzin takich jak archeologia, lingwistyka, antropologia kulturowa i biologiczna, w ramach badań o naturze kryminalistyczno-sądowej, w celu analizy przestępstw popełnionych podczas Dyktatury Wojskowej w Brazylii (1964-1985) przeciwko rdzennej populacji kraju. Wszyscy naukowcy wchodzący w skład tego projektu posiadają szeroką wiedzę i doświadczenie w swoich obszarach wiedzy, a szczególnie istotny jest fakt, iż jest to w pełni naukowy projekt badawczy, całkowicie niezależny od brazylijskiego aparatu państwa.

\section{Uwagi końcowe}

Współpraca naukowa jest nieodłączną częścią współczesnych badań naukowych. Promuje wymianę wiedzy, rozwój nauki, integrację między badaczami i wzrost potencjału rozwiązywania złożonych problemów (SONNEWALD, 2007). Wspólna praca naukowców oferuje możliwość zdobycia nowych umiejętności, spojrzenia na problem z różnych punktów widzenia oraz rozszerzenia zakresu i zasięgu badań. Wkład specjalistów z różnych dziedzin wiedzy zapewnia szeroką perspektywę, co powoduje znaczny wzrost jakości badań, ponieważ historyczna specjalizacja wiedzy znacznie ogranicza obszary 
działalności naukowców (HARA et al., 2003 ).

Taka perspektywa jest wyraźnie widoczna w dziedzinie antropologii sądowej, która ze względu na swoją złożoność i ciągły rozwój często wymyka się wąskiej definicji i otwiera się na prawdziwie multidyscyplinarną pracę. Konieczne jest jednak również otwarcie się na taką perspektywę różnych środowisk naukowych i zawodowych, zarówno w Brazylii, jak i w innych krajach, aby można było wykorzystać wszystkie zalety i możliwości zastosowania prawdziwie wielodyscyplinarnej antropologii sądowej.

Współpraca polsko - brazylijska w ramach antropologii sądowej, omówiona w tym artykule, okazała się podwójnie korzystna. Z jednej strony, polska badaczka dostrzegła w Brazylii możliwość wykorzystania swojej wiedzy akademickiej i zainteresowań naukowych w kontekście tak ogromnej potrzeby badań w zakresie antropologii sądowej, i z równoczesnym tak dużym brakiem możliwości właściwego kształcenia profesjonalistów $\mathrm{w}$ tej dziedzinie oraz niedofinansowaną infrastrukturą. $\mathrm{Z}$ drugiej strony, jej badania w ramach stażu post-doc na UNIFESP, z grantem badawczym $\mathrm{CNPq}$, pomogły w lepszym nakreśleniu sytuacji akademickiej i zawodowej antropologii sądowej w Brazylii. W tym celu konieczne było poznanie sytuacji zawodowej ekspertów kryminalnych pracujących $\mathrm{w}$ tej dziedzinie oraz wyzwań jakie napotykają w swojej codziennej pracy. Tym samym, ta współpraca pozwoliła na lepsze poznanie rzeczywistości antropologii sądowej w Brazylii. Dzięki tak dobrym wynikom naukowym oraz przyjemnej i efektywnej współpracy możliwa była kontynuacja wspólnych badań.

W takim kontekście, nawiązana została szersza współpraca naukowa Brazylia/Polska/Kanada - która również jest rzadkością w międzynarodowej przestrzeni akademickiej w dziedzinie nauk sądowych. Tego typu partnerstwa naukowe umożliwiają opracowywanie analiz krytycznych i niezależnych od aparatu państwa, często będącego bezpośrednim lub pośrednim (na skutek zaniedbania wykształcenia specjalistów i ograniczenia zasobów do prowadzenia dochodzeń kryminalistycznych) sprawcą zbrodni.

To potwierdza istotność wkładu brazylijskich uniwersytetów publicznych w kwestie społeczne, nauczając i prowadząc niezależne badania w zakresie archeologii sądowej, antropologii sądowej i prawach człowieka. Współpraca międzynarodowa wzbogaca te inicjatywy i służy wymianie wiedzy i doświadczeń. Mamy nadzieję, że partnerstwo brazylijsko-polskie w dziedzinie antropologii sądowej będzie kontynuowane i rozszerzane na inne wspólne projekty, przyczyniając się tym samym do wzrostu i rozwoju tej dyscypliny w obu krajach. 


\section{Bibliografia}

ABFA. 2020. American Board of Forensic Anthropology. Disponível em: http://theabfa.org/. Acesso em 02.07.2020.

BARAYBAR, J.P.; BLACKWELL, R. Where are they? Missing forensics and memory. Annals of Anthropological Practice v. 38, n. 1, p. 22-42. 2014.

BRASIL. Código de Processo Penal. 1941.

CUNHA, E. 2017. Considerações sobre a antropologia forense na atualidade. Revista Brasileira de Odontologia Legal - RBOL, v.4, n. 2, p. 110-117, 2017.

CUNHA, E.; CATTANEO, C. Forensic Anthropology: the state of the art. In: SCHMITT, A., CUNHA, E., PINHEIRO J., (Org.). Forensic anthropology and Forensic Medicine: complementary sciences from recovery to cause of death. Totowa, NJ: Humana Press, 2006, p. 39-56.

EAAF. 2020. Disponível em: https://eaaf.org/eaaf-en-el-mundo/argentina/. Acesso em 01.07.2020.

FRANCISCO, R.A.; VELLOSO, A.P.S.; SILVEIRA, T.C.P.; SECCHIERI, J.M.; GUIMARÃES, M.A. Antropologia forense no CEMEL de 1999 a 2009. Medicina (Ribeirão Preto), v. 44, n. 3, p. 241-248. 2011.

GASPAR NETO VV. Biological anthropology in Brazil: a preliminary overview. Vibrant - Virtual Brazilian Anthropology, v. 14, n.3, p. e14303. 2017.

GÓRKA, K.; PLENS, C.R. The academic scenario of Forensic Anthropology in Brazil. Brazilian Journal of Forensic Anthropology and Legal Medicine, v. 1, p. 29-43. 2020a.

GÓRKA, K.; PLENS, C.R. In search of identity - the field of forensic anthropology in Brazil. Profession and practice. (in press). $2020 \mathrm{~b}$.

GUIMARÃES, M.A. The challenge of identifying deceased individuals in Brazil: from dictatorship to DNA analysis. Science \& Justice, v. 43, n. 4, p. 215-217. 2003.

GUIMARÃES, M.A.; FRANCISCO, R.A.; DE ABREU E SOUZA, R.; EVISON, M.P. Forensic archaeology and anthropology in Brazil. In: GROEN, M.; MÁRQUEZ-GRANT, N.; JANAWAY, R. (Org), Forensic archaeology: current trends and future prospects. New York: Wiley. p. 215-222. 2015.

HARA, N.; SOLOMON, P.; KIM, S.L.; SONNEWALD, D. An emerging view of scientific collaboration: scientists' perspectives on collaboration and factors that impact collaboration. Journal of the American Society for Information Science and Technology, v. 54, n. 10, p. 952-965. 2003.

LEE, S.; BOZEMAN, B. The impact of research collaboration on scientific productivity. Social Studies of Science, v. 35, p. 673-702. 2005. 
NAWROCKI, S. An Outline of Forensic Anthropology. University of Indianapolis Archeology \& Forensics Laboratory (http://archlab.uindy.edu). 2006.

PLENS, C.R.; SOUZA, C.D. Arqueologia Forense: um balanço crítico da disciplina, suas abordagens e contribuições. In: AMADEO, J. (Org.), Violência de Estado na América Latina: Direitos Humanos, Justiça de Transição e Antropologia Forense. São Paulo: Editora Unifesp, 2019.

ROSENBLATT, A. Digging for the Disappeared: Forensic Science After Atrocity. Redwood City: Stanford University Press, 2015.

SONNEWALD, D. Scientific collaboration. Annual Review of Information Science and Technology, v. 41, n. 1, p. 643-681. 2007.

TARAZONA, B.; VIDAL-INFER, A.; TARAZONA-ALVAREZ, P.; ALONSOARROYO, P. Analysis of scientific production in Spanish implantology. Journal of Clinical and Experimental Dentistry, v. 9, n. 5, p. 703-711. 2017.

Submetido em: 03/08/2020

Aprovado em: 10/09/2020

Publicado: $23 / 09 / 2020$

\footnotetext{
' Zakład Antropologii Instytutu Immunologii i Terapii Doświadczalnej im. Hirszfelda Polskiej Akademii Nauk..

ii Núcleo de Ensino e Pesquisa em Arqueologia e Antropologia Forense, Laboratório de Estudos Arqueológicos (NEPAAF-LEA/UNIFESP), Departamento de História, Programa de Pós-Graduação em História, UNIFESP, São Paulo, Brasil.

iii Zgodnie z Portalem Przejrzystości Rejestru Cywilnego (Portal da Transparência do Registro Civil). Dostęp 5 czerwca $2020 \mathrm{r}$.

iv Zgodnie z Brazylijskim Rocznikiem Bezpieczeństwa Publicznego (https://forumseguranca.org.br/wpcontent/uploads/2019/10/Anuario-2019-FINAL_21.10.19.pdf). Dostęp 5 czerwca 2020 r.

${ }^{\vee} \mathrm{W}$ przeciwieństwie do Brazylii, gdzie kierunki antropologiczne koncentrują się wyłącznie na obszarach kulturalnych i społecznych. W innych krajach, np. W USA, kierunki antropologiczne dotyczą zarówno antropologii kulturowej i społecznej, jak również archeologii oraz antropologii biologicznej / fizycznej. Przez długi czas antropologia biologiczna w Brazylii była nauczana w ramach arcehologii.

vihttps://vladimirherzog.org/instituto-vladimir-herzog-repudia-ingerencia-sobre-comissao-especial-sobremortos-e-desaparecidos-politicos/ (Dostęp: 30 czerwca 2020 r.).

vii $\mathrm{Na}$ ten moment, jedynym ośrodkiem, w którym oferowane są studia magisterskie i doktoranckie $\mathrm{w}$ dziedzinie bioantropologii, jest Federalny Uniwersytet w Pará (UFPA).

viii Projekt koordynowany przez dr Cláudię Plens, dr Camila Diogo de Souza i dr Thaís Torralbo Lopez Capp i finansowany przez Humanitarian and Human Rights Resource Center (HHRRC), American Academy of Forensic Sciences (AAFS) oraz National Institute of Justice za pośrednictwem programu Forensic Technology Center of Excellence, RTI International.
} 